\title{
腫瘍の浸潤様式からみた舌癌の予後
}

\author{
岡本学・大関悟・原広子・笹栗正明 \\ 田代英雄
}

\section{Correlation between mode of invasion and prognosis of the carcinoma of the tongue}

\author{
Manabu Окамото • Satoru Ozeki • Hiroko Hara \\ Masaaki SASAgUrI • Hideo TASHIRO
}

\begin{abstract}
Relationship between the mode of tumor invasion and the prognosis was investigated in 89 primary patients with squamous cell carcinoma of the tongue treated at our Department of Oral Surgery from 1965 to 1984.

The mode of invasion of these cases was histologically investigated using initial biopsy specimens and classified into 5 grades according to the criteria of Yamamoto et al (1982); three cases were Grade 1, 19 were Grade 2, 21 were Grade 3, 35 were Grade 4 C, and 11 cases were Grade $4 \mathrm{D}$. Most of the Grade $4 \mathrm{D}$ cases showed endophtic growth pattern and belonged to stage $\mathbb{I I}, \mathbb{V}$. The histopathological findings in the cases of Grade $4 \mathrm{C}$ and $4 \mathrm{D}$ showed poorer keratinization and higher cellular pleomorphism than in the cases of Grade, $1 \sim 3$, and the histological grading by WHO classification in the cases of $4 \mathrm{D}$ were grade $\mathbb{I}$ and $\mathbb{I I}$.

Clinically, the mode of invasion was not correlated with local recurrence, although Grade $4 \mathrm{D}$ showed higher incidence of regional lymph node metastasis (81.8\%) compared with the cases of Grade $1+2(22.7 \%)$, Grade $3(38.1 \%)$, and Grade $4 \mathrm{C}(48.6 \%)$. Moreover, in the cases of Grade $4 \mathrm{C}$ and $4 \mathrm{D}$, multiple metastatic nodes were more frequently observed and the incidence of secondary metastasis was higher than in the cases of other Grades. Five-year survival rate was $48 \%$ in the case of Grade $4 \mathrm{D}$ and $70 \%$ in the cases of other Grades. Three out of 6 cases of Grade $4 \mathrm{D}$ died of neck lesion recurrence following radical neck dissection. But, 5 cases of Grade $4 \mathrm{D}$ whose primary lesions were less than 25 $\mathrm{mm}$ in diameter showed good clinical course.
\end{abstract}

Key words: carcinoma of the tongue, mode of invasion, cervical lymph node metastasis

緒

$\overline{\overline{⿳ 亠 二 口}}$

頭頸部領域覀性腫瘍患者について, その病理組織学的 所見と臨床経過との関連を検討した報告は多い1 19). そ

九州大学楿学部第 1 口腔外科学教空

（主任：田代英雄教授）

First Department of Oral Surgery, Faculty of Dentistry, Kyushu University (Chief: Prof. Hideo Tashiro)

受付日：昭和61年10月29日
れらは腫瘍头質のみの組織学的所見をとりあげたもの と, 実質のみならず間質の反応の両者より検討を加えた ものに大別されるようである。

最近, 山本らは腫瘍宿主境界部における腫瘍の浸潤様 式を 5 型に分類し, 予後との関連が深いといら一連の報 告20 25)を行っている.

今回著者らは, 当科で治療を行った舌扁平上皮癌につ いて，その浸潤様式（山本・小浜分類）と臨床経過との 関連について検討したので報告する. 


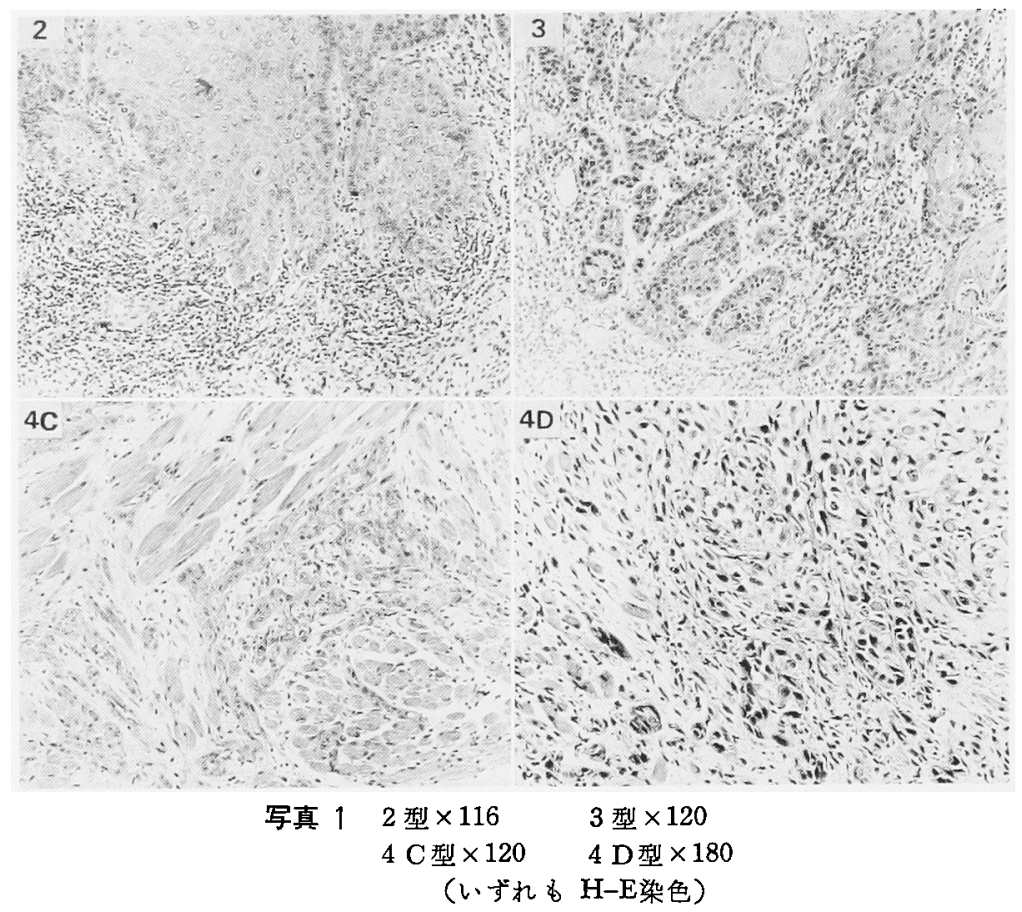

\section{対 象 症 例}

対象症例は1965年 1 月より1984年12月までの 20 年間に 九州大学附属病院口腔外科で治療を行った舌扁平上皮癌 一次症例 168 例中, 治療前生検摽本, あるい测除の及 を行った症例の切除標本で浸潤様式の判定が可能であっ た89例（生検標本71例，切除標本18例）である。广打浸 潤の程度が筋層に達していない早期浸潤癌は腫瘍実質の 性質が明確ではないため対象から除外した．すべての標 本はその症例の経過がわからないように氏名, 標本番号 を伏せて検鏡し，浸润様式は山本・小浜分類に従い，各 型の混在したものでは最も高 grade の所見で判定した.

TNM 分類は1978年 UICC 分類 ${ }^{26)}$ 亿従い, 頸部リン 節の分類は日本頭頸部腫瘍学会に上る頭頸部癌取り扱 い規約 ${ }^{27}$ に従い行った.

生存率は1986年 8 月末日を確認日として累積生存率を 算出した。

\section{結果}

89例の浸潤様式は, 1 型 3 例, 2 型19例, 3 型21例, $4 \mathrm{C}$ 型35例， 4 D型11例であった（表 1 ，写真1).

主としてTI症例である切除症例18例を約 $3 \mathrm{~mm}$ 幅に 切截し, 各ブロックごとの半連続切片に拈ける浸潤様式 を検討すると，その判定が異なる症例は11例であった。
表 1 漫潤様式別症例数

\begin{tabular}{|c|c|}
\hline 浸潤様式（山本・小浜の分類） & 症例数 \\
\hline 1 型：境界線が明憶である。 & 3 \\
\hline 2 型：境界線にやや乱れがある。 & 19 \\
\hline $\begin{array}{l}3 \text { 型：境界線は不明膫で大小の腫㻛胞巣が } \\
\text { 散在. }\end{array}$ & 21 \\
\hline $\begin{array}{ll}4 \mathrm{C} \text { 型： 境界線は不明暸で小さな腫曒胞 } \\
\text { (索状型) 巣が索状に浸潤。 }\end{array}$ & 35 \\
\hline $\begin{array}{ll}4 \mathrm{D} \text { 型： } & \text { 境界線は不明瞭で隀湯は胞巣を } \\
\text { (び漫型) つくらず，び漫性に浸潤. }\end{array}$ & 11 \\
\hline 計 & 89 (例) \\
\hline
\end{tabular}

2 型と 3 型の 混在や $4 \mathrm{C}$ 型と $4 \mathrm{D}$ 型の混在が多かった が，2，3 型の症例で一部 $4 \mathrm{C}$ 型を思わせる所見を呈す るものが 2 例あった。 また $4 \mathrm{D}$ 型の 1 例では， 5 ブロッ クのらち 2 ブロックでは原発型 $4 \mathrm{D}$, 他では続発型 $4 \mathrm{D}$ であった. 1 枚のプレパラート上に括いても浸潤様式の 混在を認めた症例るあったが，腫場辺縁部や深部といら 部位による特徴はなかった。

\section{1 ) 臨床所見と浸潤様式}

初診時平均年龄は，1+2 型59.1歳， 3 型49.3歳， 4 C 型49.6歳, 4 D型51.8歳で, $1+2$ 型はやや高龄の 傾向であった。

原発巣の大きさ（ $\mathrm{T}$ 分類）との関係では，相関はな 
く, $\mathrm{T} 1$ 症例の約 $43 \%$ は 4 型, 約 $8 \%$ は 4 型であっ た（表 2).

Stage 分類との関係では, 4 D型11例のらち Stage III, VVの症例が 8 例と多かった。

原発栄の肉眼所見では， $1 \sim 4 \mathrm{C}$ 型はいわゆる外向性 発育の症例にも認められたが，4D型はすべて潰瘍硬結 を伴う内向性発育の症例であった。

\section{2) 病理組織学的所見亡浸潤様式}

浸潤様式以外の病理組織学的所見として, 角化度, 核 分裂度，細胞異型度，WHO 分類 ${ }^{28)}$, 間質リンパ球浸潤 度をとりあげ相互の関連を検討した。

角化度は，1〜3 型では高度の症例が多いが， $4 \mathrm{C}$ 型 では中等度の症例も多くなり，4D型ではすべて中等 度，軽度の症例であった（表 3）.

核分裂度は，相関がなかった。

細胞異型度は，異型性が高度の症例は $4 \mathrm{C} ， 4 \mathrm{D}$ 型に 多く，4 D型はすべて高度異型であった。

表 $2 \mathrm{~T}$ 分類と浸潤様式

\begin{tabular}{c|r|r|r|r|c}
\hline 漫潤様式 & $1+2$ & 3 & $4 \mathrm{C}$ & $4 \mathrm{D}$ & 計 \\
\hline T 分類 & 11 & 7 & 16 & 3 & 37 \\
\hline $\mathrm{T} 1$ & 8 & 11 & 13 & 6 & 38 \\
$\mathrm{~T} 2$ & 3 & 2 & 5 & 1 & 11 \\
$\mathrm{~T} 3$ & & 1 & 1 & 1 & 3 \\
$\mathrm{~T} 4$ & 22 & 21 & 35 & 11 & 89 (例) \\
\hline 計 & & & &
\end{tabular}

表 3 角化度と浸潤様式

\begin{tabular}{c|r|r|r|r|c}
\hline 浸潤様式 & $1+2$ & 3 & $4 \mathrm{C}$ & $4 \mathrm{D}$ & 計 \\
\hline $\begin{array}{c}\text { 角化度 } \\
\text { 中高等度 }\end{array}$ & 19 & 20 & 23 & & 62 \\
軽 度 & & 1 & 11 & 7 & 22 \\
\hline 計 & 22 & 21 & 35 & 11 & 89 (例) \\
\hline
\end{tabular}

WHO 分類は, 1 〜 型ではほとんどの症例が WHO I の症例であったが， 4 C 型では WHO II の症例が増 加し，4 D型はすべて WHO II, II の症例であった（表 4 ).

間質リンパ球浸潤度は，高度浸潤は 3 型， $4 \mathrm{C}$ 型に多 く, $1+2$ 型, 4 D型では中等度の症例が多かった.

\section{3 ）原発巣の再発之浸潤様式}

当科に括ける舌癌の一次治療は，(1) 組織内照射主体 群，（2）切除主体群，（3）放射線・ブレオマイシン併用 後手術を施行する群，（4）放射線・ブレオマイシン併用 のみの群, の 4 群に大別される. 各治療群の症例数なら びに原発巣の再発率をみると, 表 5 のごとく組織内照射 群においてその再発率が低く，浸潤様式では $1+2$ 型に おいて低く，3 型に高かった。

ここで，放射線・ブレオマイシン併用後手術を施行し た18例について併用療法の組織学的効果を切除物の半連 続切片により判定し, 治療前生検標本に扣ける浸潤様式 との関連を検討した。 $4 \mathrm{D}$ 型は 3 例とも下里の分類 ${ }^{29)}$ II a 以下で効果は乏しく，1〜4 C 型では効果の良好な 症例と不良な症例があった。生検標本にて 2,3 型と判 定した症例のらち効果がそしかった 4 例は 3 例がT 3 ， T 4 の大きな症例で, 生検標本では比較的境界のはっき りした胞桇を形成していたが，残存腫瘍の浸潤様式は索 状型小さな胞兽が䇨層間に散在しており，4 C型であっ た (図 1 ).

4 ）頸部リンパ節転移様相と浸潤様式

全経過中に頸部リンパ節に組織学的転移を認めた症例

表 4 WHO 分類と浸潤様式

\begin{tabular}{c|r|r|r|r|r}
\hline WHO 分類 & $1+2$ & 3 & $4 \mathrm{C}$ & $4 \mathrm{D}$ & 計 \\
\hline I & 19 & 20 & 23 & & 62 \\
II & 3 & 1 & 12 & 8 & 24 \\
II & & & & 3 & 3 \\
\hline 詿 & 22 & 21 & 35 & 11 & 89 (例) \\
\hline
\end{tabular}

表 5 原発栄治療法別にみた原発㮺再発と浸潤様式

\begin{tabular}{|c|c|c|c|c|c|}
\hline \multirow{2}{*}{ 初回治療法 } & \multirow{2}{*}{ 原発笨再発症例 } & \multicolumn{4}{|c|}{ 再発症例の浸潤様式 } \\
\hline & & $1+2$ & 3 & $4 \mathrm{C}$ & $4 \mathrm{D}$ \\
\hline 組穖内照射群 & $4 / 39(10.3 \%)$ & & 1 & 2 & 1 \\
\hline 切除主体群 & $5 / 25(20.0 \%)$ & 1 & 2 & 2 & \\
\hline $\mathrm{BLM}+{ }^{60} \mathrm{Co} \rightarrow \mathrm{Op}$ & $4 / 18(22.2 \%)$ & 1 & 2 & 1 & \\
\hline $\mathrm{BLM}+{ }^{60} \mathrm{Co}$ & $2 / 7(28.6 \%)$ & & 1 & & 1 \\
\hline 計 & $15 / 89(16.9 \%)$ & $2 / 22(9 \%)$ & $6 / 21(28.6 \%)$ & $5 / 35(14.3 \%)$ & $2 / 11(18.2 \%)$ \\
\hline
\end{tabular}


表 6 後発耺移と浸潤様式

\begin{tabular}{|c|c|c|c|c|c|}
\hline 治療法 & $1+2$ & 3 & $4 \mathrm{C}$ & $4 \mathrm{D}$ & 計 \\
\hline $\begin{array}{l}\text { 組織内照射群 } \\
\text { 切除主体群 }\end{array}$ & $\begin{array}{l}1 / 7(14.3 \%) \\
0 / 9\end{array}$ & $\begin{array}{l}3 / 8(37.5 \%) \\
2 / 3(66.7 \%)\end{array}$ & $\begin{array}{l}9 / 13(69.2 \%) \\
1 / 9(11.1 \%)\end{array}$ & $2 / 3(66.7 \%)$ & $\begin{array}{r}15 / 31(48.4 \%) \\
3 / 21(14.3 \%)\end{array}$ \\
\hline 計 & $1 / 16(5.9 \%)$ & $5 / 11(45.5 \%)$ & $10 / 22(40.0 \%)$ & $2 / 3(66.7 \%)$ & $18 / 52(34.6 \%)$ \\
\hline
\end{tabular}

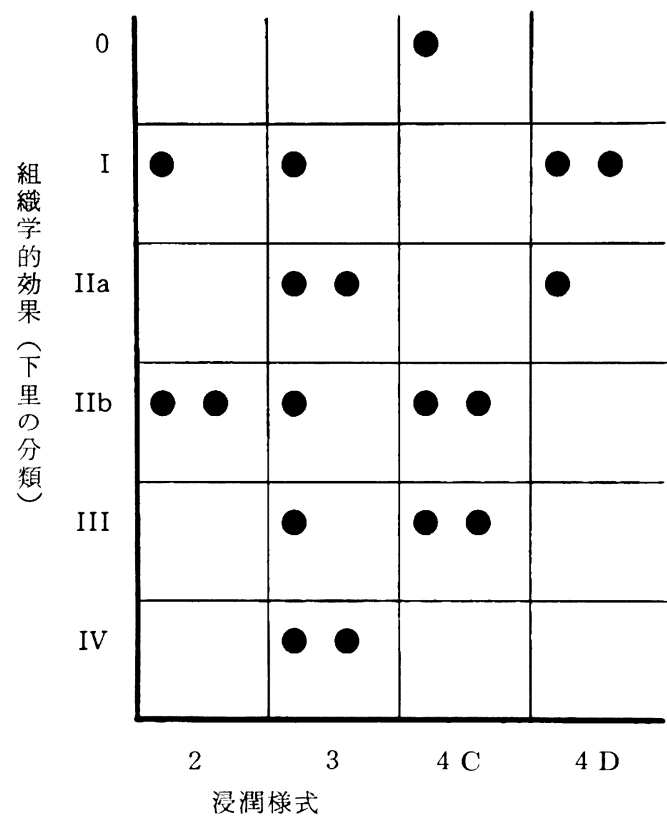

図 1 放射楾・ブレオマイシン併用症例に扣ける組 織学的効果と浸潤様式

は89例中 39 例 $(43.8 \%)$ であった。浸潤様式別にみる と, $1+2$ 型 22 例中 5 例 $(22.7 \%), 3$ 型 21 例中 8 例 $(38.1 \%), 4 \mathrm{C}$ 型35例中 17 例 $(48.6 \%), 4 \mathrm{D}$ 型 11 例中 9 例 $(81.8 \%)$ に転移を認めた。さらに転移様相では, $4 \mathrm{C}$ ， 4 D型の症例は転移リンパ節が 2 個以上で, 複数 の領域にわたる転移が多く，中内深頸りンパ節より下方 の領域への転移が多いことが特徵であった（図2)。ま た両側頸部転移症例 3 例中 2 例は $4 \mathrm{D}$ 型であった。

初診時 NO であった 57 例中 18 例 $(31.6 \%)$ に後発転 移を認めた。 NO 症例は原発巣治療として組織内照射も しくは切除を主体として施行しているが，治療法別に後 発転移をみると, 組織内照射群に打ける $4 \mathrm{C} ， 4 \mathrm{D}$ 型症 例に, 切除主体群に打ける 3 型症例に頻度が高かった (表 6 ).

\section{5 ）生存率之浸潤様式}

浸潤様式別に累積生存率を算出すると， 1 4 C 型で は差がなく，5年生存㳯約70\%であったが，4 D型は 2

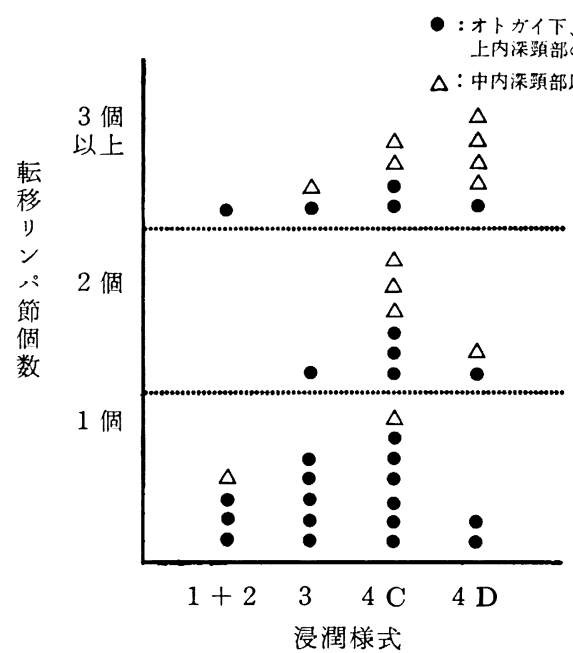

図 2 頸部リンパ節転移様相

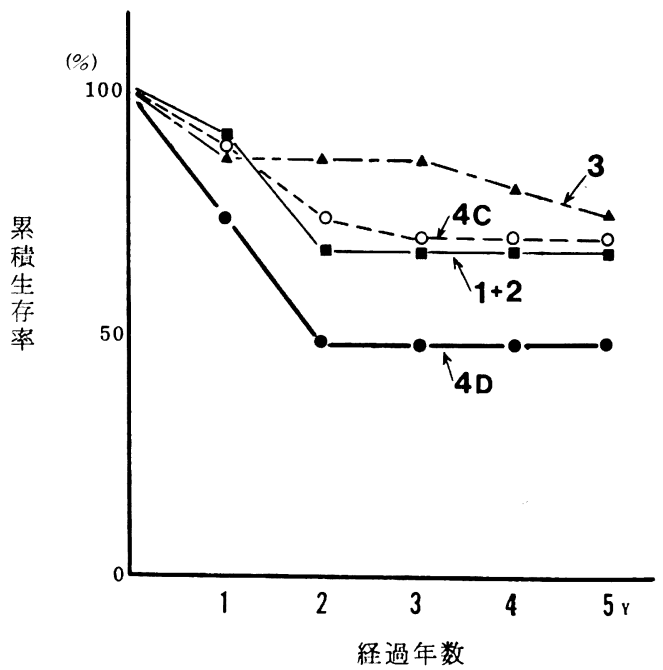

図 3 浸潤㮞式別累積生存率

年生存率ですでに約 $48 \%$ と不良であった（図3）.

腫癔死は， $1+2$ 型22例中 5 例 $(22.7 \%), 3$ 型 0 例, $4 \mathrm{C}$ 型35例中 10 例 $(28.6 \%), 4 \mathrm{D}$ 型 11 例中 6 例 $(54.5$ 
表 74 D型症例臨床経過

経過不良群

\begin{tabular}{|c|c|c|c|c|c|c|c|c|c|c|c|}
\hline \multicolumn{2}{|c|}{ 症 例 } & \multirow{3}{*}{$\mathrm{T}$} & \multirow{3}{*}{$\mathrm{N}$} & \multicolumn{2}{|l|}{ 初回治療法 } & \multirow{3}{*}{ 転移 } & \multicolumn{3}{|c|}{ 経 過 } & 転 & 㷌 \\
\hline \multirow[b]{2}{*}{ 性 } & \multirow[b]{2}{*}{ 年䊀会 } & & & & & & 後発 & & & \multirow[b]{2}{*}{ 生 死 } & \multirow[b]{2}{*}{ 期 間 } \\
\hline & & & & 原 発 宩 & 頸 部 & & & 原発栄 & 頸部 & & \\
\hline 1. 男 & 56 & 2 & 1 & Needling & RND & + & & + & & 原発单死 & $4 \mathrm{~m}$ \\
\hline 2. 男 & 45 & 3 & 3 & $\mathrm{BLM}+{ }^{60} \mathrm{Co}$ (姑息的) & & + & & & & 原発栄死 & $3 \mathrm{~m}$ \\
\hline 3. 女 & 73 & 2 & 1 & Op. $+{ }^{60} \mathrm{Co}$ & RND & + & & & + & 頙転移死 & $1 \mathrm{y} 1 \mathrm{~m}$ \\
\hline 4. 男 & 46 & 4 & 3 & $\mathrm{BLM}+{ }^{60} \mathrm{Co}+\mathrm{Op}$ & RND & + & 反 + & & + & 頸転移死 & $1 \mathrm{y} 1 \mathrm{~m}$ \\
\hline 5. 男 & 36 & 2 & 3 & $\mathrm{BLM}+{ }^{60} \mathrm{Co}+\mathrm{Op}$ & 両 RND & 両 + & & & + & 䫇転移死 & $11 \mathrm{~m}$ \\
\hline 6. 男 & 69 & 2 & 0 & Needling & & & + & & & 肺転移死 & 1 y $1 \mathrm{~m}$ \\
\hline
\end{tabular}

経過良好群

\begin{tabular}{r|c|c|c|l|c|c|c|c|c|c|c} 
7. 女 & 65 & 1 & 0 & BLM+Op. & & & & & & 生 & $5 \mathrm{y} \sim$ \\
8. 女 & 43 & 1 & 0 & Op.+Needling & & & + & & & 生 & $5 \mathrm{y} \sim$ \\
9. 男 & 58 & 1 & 1 & Needling & RND & + & & & & 生 & $4 \mathrm{y} 7 \mathrm{~m}$ \\
10. 男 & 55 & 2 & 1 & Needling & RND & & & & & 生 & $5 \mathrm{y} \sim$ \\
11. 男 & 24 & 2 & 1 & BLM $+{ }^{60} \mathrm{Co}+$ Op. & RND & + & & & & 生 & $2 \mathrm{y} 2 \mathrm{~m}$ \\
\hline
\end{tabular}

RND：全頸部郭清術

\%)であった。

$4 \mathrm{D}$ 型症例のらち経過不良であった症例では, 高度進 展のために姑息的治療となった 1 例と他の 1 例に原発巣 の再発をきたし，その制御ができなかった。頸部リンバ 節転移が複数個，かつ中内深頸部を含む複数領域へ認め られた 3 例では頸部再発をきたし死亡し，1 例は肺転移 にて死亡した。これら経過不良の 6 例はいずれも原発巣 の長径が $26 \mathrm{~mm}$ 以上の 症例であった。一方, $4 \mathrm{D}$ 型症 例でも $25 \mathrm{~mm}$ 以下の 比較的早期の 5 例はすべて経過良 好であった。 5 例のらち頸部リンパ節転移は 3 例に認め たが，1個あるいは1 領域に限局した症例であり，原発 巣, 頸部ともに再発を認めず, 経過している（表 7).

\section{考察}

\section{1) 臨床・病理組織学的所見と浸潤樣式}

今回検討を行った臨床所見のらち浸潤様式との関連を 認めたものは, $1+2$ 型では初診時年龄が他より高かっ たこと，4 D型では Stage III, IV の症例が多かったこ と, 内向型発育症例であったことの 3 点である。また病 理組織学的所見では, $1 \sim 3$ 型では高度角化型で, 細胞 異型度は軽度,もしくは中等度であり, WHO 分頑 I の症 例が多かった。一方，4 C，4 D型では角化度の低い症 例が增光，細胞異型度は高度で，WHO 分類 II, II $の$ 症 例が多くなっていた．とくに $4 \mathrm{D}$ 型はすべて WHO 分 類 II，III 低分化の症例であった。 山本ら ${ }^{21)}$ は，各種臨
床・病理組織学的所見と浸潤様式との関連について, 発 育様式, 分化度, 核異型度, 単核細胞浸潤とはある程度 の関連があったが，分裂活性とは明らかな関連を認めな かったと述べており, 著者らの結果と, ほぼ同様であっ た.

\section{2) 臨床経過と浸潤様式}

a. 原発巣の再発

原発巣の再発については，4 C，4 D型では高い再発

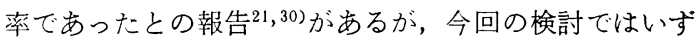
れの治療群においても浸潤様式と原発觉再発率との間に は相関を認めず，4 C，4 D型でも再発率は高くなかっ た。

まず，組織内照射群では，高線量によりいずれの浸潤 様式の腫瘍も壊死におちいらせ, 再発は腫瘍の浸潤範囲 の正確な把握の失敗や, 刺入困難な部位などの線量が不

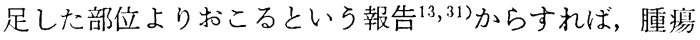
の性格よりも手技面での要因が関与するのではないかと 思われた。それゆえ $4 \mathrm{C}, 4 \mathrm{D}$ 型の症例では, その浸潤 傾向が強いことを考虑して, 腫缶浸潤先端部への線量が 不足しないように気をつけねばならない。

次に切除群では, 比較的小さい症例に適応している が， T 1 症例の約 $51 \%$ は $4 \mathrm{C}, 4 \mathrm{D}$ 型であったことよ り, 切除範囲の設定に際し注意が必要である.

術前に放射線・ブレオマイシンの併用を行った症例に おいては, その原発栄再発は併用療法の効果と切除範囲 に左右される。山本ら ${ }^{20)}$ はブレオマイシン術前単独投与 
による $50 \%$ 以上腫愓縮小率は，1 $1 \rightarrow 4$ 型にしたがい拉の おの $100 \% ， 70 \% ， 37.5 \% ， 36.4 \%$ で相関があったと述 ベ, 天笠ら ${ }^{17)}$ は舌癌のブレオマイシン単独治療による腫 瘍消失例における浸潤様式では，4 D型が 1 例もなかっ たことより，び漫性に高度浸潤する症例ではその効果が そしいと述べている。 そのほかにも浸潤様式とブレオマ イシン，あるいは放射線の治療効果については，4 型は 効果が乏しいとする報告 ${ }^{13,14)}$ が多くみられる.今回の 検討では，放射線・ブレオマイシンの併用効果に拈いて もやはり $4 \mathrm{D}$ 型ではその組織学的効果は乏しかった。視 診，触診による臨床効果においては $50 \%$ 以上の腫瘍縮小 を認めても，組織学的には多くの残存腫瘍を認めたこと より,切除籁囲を縮小することは危険である. 一方, 1 〜 $4 \mathrm{C}$ 型の症例ではその組織学的効果が良好な症例と不良 な症例があった。この理由としては, 畽瘍の一部を採取 した生検標本により浸潤様式の判定がなされたことでそ の腫瘍全体の浸潤様式と異なっていたこと，あるいは 浸潤様式以外に併用療法効果を左右する因子があるので はないかという2 点が考えられた. 生検標本における浸 潤様式が 2,3 型の症例で併用効果の乏しい症例では, その切除標本における残存腫序には 4 C型が多く認めら れた. 井上2) は舌癌摘出標本による検討から部位により 様々の組織像が認められることを示しているが，今回， 切除標本よりの半連続切片における検討においても T 1 と比較的小さな症例にもかかわらず，各切片に拈ける浸 潤様式の不一致が約 $61 \%$ に認められた。 それゆえ大きな 症例では部位により組織像の違いが当然予想されること から，一部の生検標本で 3 型と判定された症例の中に も，4 C，4 D型症例の存在を否定できず，浸潤様式が 併用効果に強く関連しているかどらかは4 D型を除い て，明らかではなかった。したがって浸潤様式のみから その併用効果を予測することは困難であり, その他の臨 床, 病理組織学的所見と併用効果との関係について今後 の検討が必要であると思われた。

\section{b. 頸部リンパ節転移}

宮川 ${ }^{24)}$ は頸部リンパ節転移の頻度が 1 型では $14.1 \%$ と低いのに対して，4 C型では66.7\%，4 D型で は75.0\%と高頻度であったと述べ, Yamamoto ら ${ }^{23)}$ は その転移様相について，4 型では転移リンパ節の個数が 多かったと述べている．立花 ${ }^{30}$ は舌癌の転移陽性例に扰 ける浸潤様式は 4 C 型 $48 \%$ ４４型 $21 \%$ と計 $69 \%$ が 4 型 であったと述べている. 今回の検討では，1４Ｄ型に したがい転移頻度は上昇しており，とくに 4 D型では $81.8 \%$ と高頻度であった。 また $4 \mathrm{C} ， 4 \mathrm{D}$ 型の転移様相 は, 転移リンパ節が複数個, 複数領域にわたる転移であ り，予後不良となる因子32)が多かった。

後発転移の可能性が高い症例を予測することは予防的 頸部郭清の是否や経過観察において意味あることと思わ れ，浸潤様式との関連を㭘討した. Stage I，II の症 例
は切除あるいは組織内照射を施行しているが, 後発転移 は組織内照射群に多くみられ，とくに $4 \mathrm{C} ， 4 \mathrm{D}$ 型に高 頻度であった。この理由として，4 C，4 D型のように 浸潤傾向が強い症例は元来 micro metastasis が多いこと や，腫場実質内に小線源を刺入する器械的操作に起因し て容易に転移が促進される33,34) といらことも考えられる かもしれない、山本ら ${ }^{25)}$ は 4 型に後発転移が多く，とく に $4 \mathrm{D}$ 型では頸部再発の制御が困難であったことより， $\mathrm{T} 1 \mathrm{NO}$ 症例でも $4 \mathrm{D}$ 型は予防郭清を勧めている. 当 科では後発転移症例の予後が初回治療時に転移を認めた

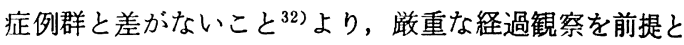
して予防郭清は施行していないが，その時期を逸した症 例では転移リンパ節節外浸潤などの予後不良となる転移 様相を呈する場合があり, 今後予防郭清の施行を検討す る上で， $4 \mathrm{C} ， 4 \mathrm{D}$ 型はその指標の 1 つとなるかもしれ ない.

\section{c. 生存率}

生存率と浸潤様式との関連については Yamamoto ら ${ }^{22)}$ は $\rightarrow 4 \mathrm{D}$ 型にしたがい生存率は低下したと述へて いるが，今回の検討では $1 〜 4 \mathrm{C}$ 型は差がなく，4 D型 のみが不良であった。しかし $4 \mathrm{D}$ 型でも原発巣の長径が $25 \mathrm{~mm}$ 以下の 比較的早期の 5 例はいずれも経過良好で あった. したがって $4 \mathrm{D}$ 型では, 原発巣が $26 \mathrm{~mm}$ 以上 の $\mathrm{T} 2$ 症例，および T $3 ， \mathrm{~T} 4$ 症例が問題となる。これ に対しては初回治療に際して，その高度浸潤珄や，放射 線・ブレオマイシン併用効果が期待できないことを考虑 し, 十分な safety margin を設けた上での根治切除が必 要であると思われた。 またその長径が $25 \mathrm{~mm}$ 以下の症 例では頸部転移の制御は可能であったのに対して，大き な症例に拈いては，予後不良となる転移様相を認め，そ の制御が困難であったことは，4 D 型の高度に進展する 傾向を示唆するものと思われた。

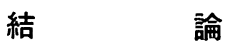

20年間に当科で治療を行った舌扁平上皮癌一次症例89 例について, その腫瘍の浸潤様式と臨床, 病理組織学的 所見との関連, ならびに浸潤様式と臨床経過との関連に ついて検討を加え, 以下の結論を得た。

1. 浸潤様式 $4 \mathrm{D}$ 型は, Stage III, IV の症例が多く、す べて内向型発育であった。

2. 浸潤様式は角化度, 細胞異型度, WHO 分類と関 連があり，4 D型は低角化，高度細胞異型，WHO II， IIIの症例であった。

3. 原発栄の一次治療法別にみた 再発率は浸潤様式と 関連がなかった。

4. 頸部リンパ節転移頻度は $1+2$ 型 $22.7 \%, 3$ 型 $38.1 \% ， 4 \mathrm{C}$ 型 $48.6 \% ， 4 \mathrm{D}$ 型 $72.2 \%$ と関連を認め, $4 \mathrm{C}, 4 \mathrm{D}$ 型では複数個, 複数領域への転移が多く, 
また中内深頸リンパ節より下方の領域への転移も多かっ た。

5. 後発転移は $4 \mathrm{D}$ 型でその頻度が高く，組織内照射 群では 4 C型も高頻度であった。

6. 累積生存率は $1 \sim 4 \mathrm{C}$ 型では差がなく，比較的良 好であったが，4 D型は不良であり，腫瘍死をした $4 \mathrm{D}$ 型 6 例中 3 例は頸転移死であった。しかし $4 \mathrm{D}$ 型でも原 発巣の長径が $25 \mathrm{~mm}$ 以下の小さな 症例は経過良好であ った.

以上，主として生検標本により判定した浸潤様式によ って検討を加えたが，腫瘍全体の浸潤様式との不一致に よる限界はあるものの，4 C，4 D型に限れば頸部リン ハ節転移との関連が示された。 また放射線・ブレオマイ シン併用療法効果については，浸潤様式を含め，他の臨 床, 病理組織学的所見との総合的な検討が必要であると 思われた。

本論文の要旨は, 第17回日本口腔科学会九州地方部会 （熊本市，1984年）に扣いて報告した。

\section{引用文 献}

1) Broders, A.C.: Squamous cell epithelioma of the lip: A study of five hundred and thirty seven cases. JAMA 74: 656-664 1920.

2) 井上 篤: 舌癌の組織学的研究. 福岡医誌 46: 1039-1059 1955.

3) Jakobsson, P.A., Eneroth, C.M., et al.: Histological classification and grading of malignancy in carcinoma of the larynx. Acta radiologica 12: 1-8 1973 .

4) Eneroth, C.M. and Moberger, G.: Histological malignancy grading of squamous cell carcinoma of the palate. Acta Otolaryng 75: 293-295 1973.

5) 牧野利雄: 舌癌の放射線治療の改善に関寸る研 究。日医放 33：308-322 1973.

6）藤野博，田代英雄，他：主として間質反応上 りみた口腔粘膜癌。口科誌 23：362-373 1974.

7) Lund, C., Søgaard, H., et al.: Epidermoid carcinoma of the tongue. Histologic grading in the clinical evaluation. Acta Radiologica Therapy Physics Biology 14: 513-521 1975.

8) Willén, R., Nathanson, A., et al.: Squamous cell carcinoma of the gingiva. Histological classification and grading of malignancy. Acta Otolaryngol 79: 146-154 1975.

9) 藤谷哲造, 志水雄輔, 他: 舌瘦の病理組織学的 覀珄度と放射線治療後の臨床経過との関速. 瘦 の臨床 24:661-665 1978.

10）作田正義：癌細胞の転移形成に関する研究。口 科誌 28: 525-539 1979 .

11）清水正柌：口腔粘膜扁平上皮瘦の化学療法効果
判定に打ける腫演条件因子としての組織所見の 検討。癌の臨床 26：641-644 1980.

12）深澤高士：舌放射線治療後の局所再発に関する 臨床病理学的研究.耳舅臨床 75: 501-515 1982.

13）高島均, 天津陸郎：下咽頭癌に打ける放射線 治療の臨床的ならびに病理組織学的研究. 日癌 治 18: 906-915 1983.

14）甲村雄二, 細田 峪, 他：舌癌に対するブレオ マイシン単独投与と放射線単独昭射の抗腫湯効 果に関する病理組織学的覞察. 癌と化学療法 10: 1320-1327 1983.

15）作田正義, 幸 雅樹, 他：口腔癌の臨床病理組 織学的検討. 口科誌 34：285-293 1985.

16）佐野和生, 井口次夫, 他：口腔領域扁平上皮痹 の臨床病理学的推察. 日口外誌 31：1-9 1985.

17）天笠光雄, 塩田重利, 他：ブレオマイシンの単 独洽療効果に関する臨床的, 病理組織学的研 究。 日癌治 20：106-113 1985.

18）中村太保：放射線治療成績よりみた舌癌の予後 因子と病理組織像との関連性について，阪大㐘 学雑誌 31: 209-224 1986.

19）花沢秀：舌癌に打ける組織学的悪性度 (Willén 分類変法) と頸部リンパ節転移との関 連性。日癌治 21：34-41 1986.

20）山本悦秀, 砂川元, 他：口腔粘膜癌の浸潤様 式と Bleomycin 感受性。癌の臨床 27: 158315891981.

21）山本悦秀, 砂川 元, 他：び漫性浸潤型口腔扁 平上皮に関する研究。 日外誌 28：1471-1479 1982.

22) Yamamoto, E., Kohama, G., et al.: Mode of invasion, Bleomycin sensitivity, and clinical course in squamous cell carcinoma of the oral cavity. Cancer 51: 2175-2180 1983.

23) Yamamoto, E., Miyakawa, A., et al.: Mode of invasion and lymph node metastasis in squamous cell carcinoma of oral cavity. Head \& Neck Surg 6: 938-947 1984.

24）宮川明, 小浜源郁, 他：口腔癌の頸部リンパ 節転移に関する臨床病理学検討。日口外誌 29 : 1555-1561 1983.

25）山本悦秀, 小浜源郁, 他: 原発巣切除後, 局所 再発なく後発転移をきたした非進展舌癌の㭘 討. 日口外誌 30：823-831 1984.

26) Harmer, M.H.: TNM Classification of Malignant Tumors. 3rd, UICC, Geneva, 1978, p 23-26.

27) 頭頸部癌取り扱い規䄪。日本頭頸部腫瘍学会 編，第 1 版，金原出版，東京，1982，2-4頁.

28) Wahi, P.N., Cohen, B., et al.: Histological typing of oral and oropharyngeal tumors, $\mathrm{p}$ 17, WHO, Geneva, 1971.

29) Shimosato, Y., Obosi, S., et al.: Histological evaluation of effects of radiotherapy and 
chemotherapy for carcinomas. Jap J Clin Oncol 1: 19-35 1971.

30）立花忠夫：口膑領域扁平上皮癌の頚部リンパ節 転移に関する臨床的ならびに病理組織学的研 究. 口病誌 52: 521-544 1985.

31）森田皓三, 林繁次郎, 他：舌癌の放射線治療成 績。癌の臨床 23：511-518 1977.

32) 岡本学, 大関悟, 他：口腔癌に扣忷る頸部
郭清術施行例 の検討. 日口外誌 31 : 554-562 1985.

33）中村社綱, 田代英雄, 他 : 口腔癌治療後の頸部 転移発症例について。日口外誌 25：1034-1038 1979.

34）奥田 稔, 吉井功, 他：舌癌の転移につい て。耳喉 36: 907-914 1964. 